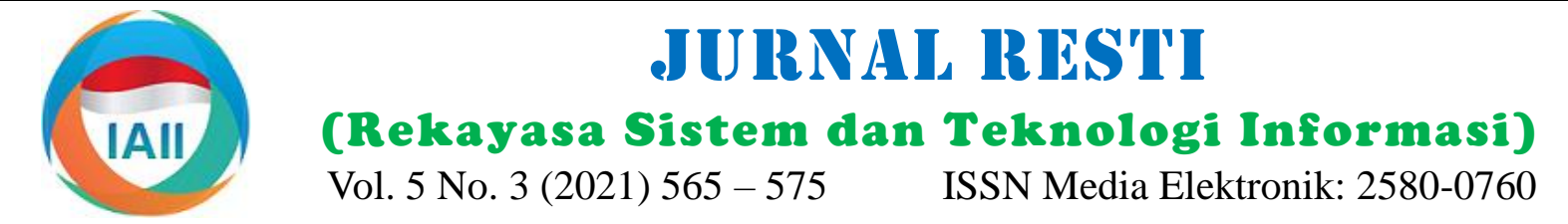

\title{
Penentuan Klaster Koridor TransJakarta dengan Metode Majority Voting pada Algoritma Data Mining
}

\author{
Arief Wibowo ${ }^{1}$, Moh Makruf ${ }^{2}$, Inge Virdyna ${ }^{3}$, Farah Chikita Venna ${ }^{4}$ \\ 1,2,3,4 Program Studi Magister Ilmu Komputer, Fakultas Teknologi Informasi, Universitas Budi Luhur \\ 1'arief.wibowo@budiluhur.ac.id, ${ }^{2} 1911601175 @$ student.budiluhur.ac.id, ${ }^{3} 1911601142 @$ student.budiluhur.ac.id, \\ ${ }^{4}$ 1911601050@student.budiluhur.ac.id
}

\begin{abstract}
The Covid-19 pandemic has made many changes in the patterns of community activity. Large-Scale Social Restrictions were implemented to reduce the number of transmission of the virus. This clearly affects the mode of transportation. The mode of transportation makes new regulations to reduce the number of passenger capacities in each fleet, for example, TransJakarta services. This study will categorize the TransJakarta corridors before and during the Covid-19 pandemic. The clustering method of K-Means and K-Medoids is used to obtain accurate calculation results. The calculations are performed using Microsoft Excel, Rapid Miner, and Python programming language. The clustering results obtained that using K-Means algorithm before Covid-19 pandemic, an optimum number of clusters is 3 clusters with DBI (Davies Bouldin Index) value is 0.184 , and during Covid-19 pandemic, the optimum number of clusters is 2 clusters with DBI value is 0.188. Meanwhile, when using the K-Medoids algorithm before the Covid-19 pandemic, an optimum number of clusters is 3 clusters with the DBI value is 0.200, and during the Covid-19 pandemic, an optimum number of clusters is 4 clusters with the DBI value is 0.190. The final cluster is determined using the majority voting approach from all the tools used.
\end{abstract}

Keywords: covid-19, transjakarta, clustering, davies bouldin index, majority voting

\begin{abstract}
Abstrak
Pandemi Covid-19 menjadikan banyak perubahan dalam pola aktifitas masyarakat. Pembatasan Sosial Berskala Besar (PSBB) diimplementasi guna menekan angka penularan virus tersebut. Hal ini jelas berpengaruh terhadap moda transportasi. Moda transportasi membuat aturan baru untuk mengurangi jumlah kapasitas penumpang di setiap armada, sebagai contoh layanan Transjakarta. Penelitian ini akan mengelompokkan koridor TransJakarta sebelum dan selama masa pandemi Covid-19. Metode klasterisasi K-Means dan K-Medoids digunakan untuk mendapatkan hasil perhitungan yang akurat. Perhitungan dilakukan menggunakan tools Microsoft Excel, Rapid Miner dan bahasa pemrograman Python. Berdasarkan hasil pengelompokan yang diperoleh dari penggunaan algoritma K-Means sebelum masa pandemi, jumlah cluster optimal adalah 3 cluster dengan nilai DBI (Davies Bouldin Index) 0,184, dan selama masa pandemi, jumlah cluster optimal adalah 2 cluster dengan nilai DBI 0,188. Sementara itu, bila menggunakan algoritma K-Medoids sebelum masa pandemi, jumlah cluster optimal adalah 3 cluster dengan nilai DBI 0,200, dan selama masa pandemi, jumlah cluster optimal adalah 4 cluster dengan nilai DBI 0,190. Penentuan cluster akhir menggunakan pendekatan metode majority voting dari semua tools yang digunakan.
\end{abstract}

Kata kunci: covid-19, transjakarta, klasterisasi, davies bouldin index, pemilihan mayoritas

\section{Pendahuluan}

Indonesia memiliki sistem transportasi bus cepat atau

Bus Rapid Transit (BRT) pertama di Asia Tenggara dan Corona Virus Disease 2019 (Covid-19) merupakan Asia Selatan yaitu TransJakarta [1]. TransJakarta penyakit yang disebabkan oleh virus baru yang berasal dirancang untuk warga Jakarta melalui pelayanan yang dari Sars-CoV-2. Kasus pertama Covid-19 ditemukan cepat, nyaman, dan harga terjangkau. TransJakarta pada tanggal 31 Desember 2019 di kota Wuhan, beroperasi sejak tanggal 1 Febuari 2004. Menurut situs Tiongkok. Pada 11 Maret 2020, World Health transjakarta.co.id, hingga saat ini TransJakarta tersedia Organization (WHO) menyatakan Covid-19 merupakan 
pandemi global. Kasus pertama positif Covid-19 di Indonesia dikonfirmasi pada 2 Maret 2020 [2].

Kasus terkonfirmasi positif Covid-19 di Indonesia semakin meningkat. Untuk mengurangi penyebaran virus Covid-19, pemerintah menerapkan berbagai kebijakan seperti social distancing atau physical distancing dan kebijakan Pembatasan Sosial Berskala Besar (PSBB). PSBB ditetapkan oleh Menteri Kesehatan RI usulan Gubernur atau Walikota. Jabodetabek menerapkan kebijakan PSBB. Namun kebijakan tersebut dapat mengakibatkan penurunan penumpang angkutan umum seperti TransJakarta. Selama ditetapkan PSBB, TransJakarta tetap beroperasi namun dibatasi jumlah koridor, armada dan intensitas waktu operasi.

Penelitian terdahulu mengenai clustering yaitu Adi Supriyatna tentang clustering koridor TransJakarta menggunakan algoritma K-Means. Penelitian tersebut diproses melalui Microsoft Excel dan Rapid Miner Studio menghasilkan 3 cluster (jumlah penumpang terbanyak, sedang, dan rendah). Limitasi dari penelitian ini adalah jumlah dataset yang dipakai kurang banyak [3].

Penelitian lain membahas penggunaan metode K-Means untuk clustering data penjualan. Data diolah melalui perhitungan manual dan Rapid Miner, hasil dari penelitian yaitu menghasilkan 3 cluster barang yang dijual yaitu laris, kurang laris, dan cukup laris. Limitasi dari penelitian adalah rentang waktu sampel yang digunakan kurang panjang yaitu selama 3 bulan [4]. Pada kasus kebakaran hutan yang dibahas pada penelitian oleh Sukamto, dkk menggunakan algoritma Chebysev K-Means menghasilkan 3 cluster (daerah sangat rawan, daerah rawan dan daerah tidak rawan). Pengklasteran pada penelitian ini sudah optimal karena nilai DBI yang diperoleh 0,361. Kekurangan pada penelitian ini adalah tidak menggunakan tools data mining untuk perhitungan sehingga dikhawatirkan perhitungan yang dilakukan tidak akurat [5].

Penelitian yang membahas sektor pertanian mengenai analisa terhadap produktifitas penanaman padi pada 34 provinsi di Indonesia menggunakan metode klasterisasi K-Means. Hasil dari penelitian menunjukkan bahwa metode klaterisasi K-Means mampu memberikan hasil yang optimal dengan menghasilkan 3 klaster, yaitu 4 provinsi dengan produktivitas tinggi, 19 provinsi dengan produktifitas menengah dan 11 provinsi dengan produktifitas rendah. Kekurangan dari penelitian ini adalah tidak adanya evaluasi untuk menentukan jumlah klaster optimal [6].

Penelitian lainnya dari Indra Gunawan tentang clustering perkembangan kasus COVID-19 menggunakan algoritma K-Medoids. Pengolahan data pada penelitian tersebut diproses melalui $R$ Studio,
Geoda, Statscan dan QGis menghasilkan optimum jumlah kelompok sebanyak tiga kategori (tinggi, sedang, rendah). Limitasi dari penelitian adalah hanya menggunakan tiga variable yaitu positif, sembuh, dan meninggal, dapat ditambahkan variable suspek dan pasien negative [7]. Penelitian klasterisasi juga dilakukan pada sektor kesehatan. Penelitian dari Tri Juninda, dkk menyimpulkan bahwa algoritma KMedoids dapat melakukan pengelompokan penyakit yang ada di Pekanbaru Riau dengan pengklasteran terbaik dilakukan dengan 4 cluster, sehingga proses implementasi pada sistem dan analisis dapat diterapkan berdasarkan penelitian tersebut. Kekurangan pada penelitian ini adalah tidak menggunakan tools data mining untuk perhitungan sehingga dikhawatirkan perhitungan yang dilakukan tidak akurat [8]. Penelitian yang dilakukan oleh Dini Marlina, dkk mengenai pengelompokan pada data sebaran anak cacat yang ada pada Provinsi Riau dengan menggunakan algoritma KMeans dan K-Medoid. Hasil dari komparasi algoritma K-Medoids dan K-Means melalui validitas Silhoutte Coefficient menghasilkan nilai validitas algoritma KMedoids sebesar 0.5009, sedangkan nilai validitas algoritma K-Means sebesar 0.1443. Hal ini menunjukkan algoritma K-Medoids lebih baik dibandingkan dengan algoritma K-Means. Limitasi dari penelitian ini adalah ruang lingkup yang digunakan terbatas di provinsi Riau, belum mencakup daerah lain [9].

Penelitian oleh Pramesti, dkk tentang Implementasi metode K-Medoids Clustering untuk pengelompokan dalam data potensi kebakaran Hutan/Lahan berdasarkan persebaran titik panas (Hotspot), menghasilkan bahwa jumlah cluster dan jumlah data berpengaruh terhadap hasil kualitas dari cluster. Limitasi dari penelitian ini adalah data yang digunakan terbatas hanya satu bulan, dan perlu dilakukan teknik pemilihan parameter yang digunakan [10]. Pada penelitian oleh Defiyanti, dkk tentang Optimalisasi K-Medoid dalam Pengklasteran Mahasiswa Pelamar Beasiswa dengan Cubic Clustering Criterion, membahas tentang jenis data terbaik dalam pengelompokan beasiswa dihitung dengan nilai Cubic Clustering Criterion (CCC) menghasilkan tiga buah pengelompokan. Dataset dengan kodifikasi keseluruhan data menempati predikat terbaik dalam keseragaman dalam pengelompokan. Limitasi pada penelitian ini adalah jumlah data yang digunakan sedikit [2].

Pada penelitian ini, penulis mengelompokkan koridor TransJakarta berdasarkan tiga variabel yaitu jumlah penumpang, jarak rute antar koridor, dan jumlah halte yang dilewati. Selama pandemi Covid-19 dan kebijakan PSBB, Transjakarta hanya mengoperasikan 13 koridor utama tanpa mengurangi jumlah halte yang dilewati tiap koridor. Peneliti melakukan studi ini berdasarkan dua hal utama, yaitu adanya perubahan pengaktifan koridor TransJakarta yang mendorong masyarakat untuk 
mengganti rute perjalanan yang biasa dilakukan menjadi Berdasarkan kebijakan pemerintah yang membatasi rute lain. Faktor kedua, berdasarkan perubahan yang angkutan umum selama Covid-19, maka peneliti terjadi, peneliti ingin mengetahui koridor mana yang menggunakan 13 koridor utama dengan trayek jenis mengalami lonjakan penumpang yang signifikan dan BRT. 13 Koridor tersebut adalah Koridor 1 (Blok Mkoridor mana yang membutuhkan armada lebih dan Kota), Koridor 2 (Pulogadung 1 - Harmoni), Koridor 3 tambahan jumlah petugas. Dengan demikian maka (Kalideres - Pasar Baru), Koridor 4 (Pulogadung 2 pertanyaan penelitian yang akan dipecahkan adalah, Dukuh Atas 2), Koridor 5 (Kampung Melayu - Ancol), bagaimana model klasterisasi terhadap koridor-koridor Koridor 6 (Ragunan - Dukuh Atas 2), Koridor 7 Transjakarta sebelum dan sesudah pandemi Covid-19 (Kampung Rambutan - Kampung Melayu), Koridor 8 terjadi di Jakarta. Hal ini menjadi penting karena klaster (Lebak Bulus - Harmoni), Koridor 9 (Pinang Ranti yang terbentuk nantinya akan menjadi bagian dari Pulit), Koridor 10 (PGC 2 - Pluit), Koridor 11 pertimbangan yang dilakukan oleh Badan Pengelola (Pulogebang - Kampung Melayu), Koridor 12 dalam manajemen operasional koridor bus Transjakarta. (Penjaringan - Tanjung Priok), dan Koridor 13 (CBD

Pendekatan algoritma klasterisasi data mining dipilih karena berdasarkan literatur yang diulas, diketahui bahwa metode klasterisasi dengan K-Means dan KMedoids mampu mencapai hasil yang optimal dalam pembentukan pola klasterisasi.

Studi literatur terdahulu yang membahas tentang pengelompokan koridor TransJakarta belum ada yang mengkomparasi penggunaan algoritma K-Medoids dan K-Means. Hasil dari penelitian sebelumnya, algoritma k-Means dan K-Medoids terbukti memiliki kinerja yang baik, sehingga peneliti ingin menguji kinerja algoritma tersebut dengan data yang tersedia.

Pada penelitian ini, pengelompokkan data menggunakan Rapid Miner, Phyton dan Microsoft Excel. Selanjutnya hasil akhir penentuan cluster menggunakan majority voting berdasarkan semua tools yang digunakan. Pemilihan metode majority voting menjadi penting agar pengambilan keputusan menjadi kuat berdasarkan keputusan mayoritas [11].

\section{Metode Penelitian}

Penelitian ini mengklasterisasi koridor TransJakarta berdasarkan jumlah penumpang, jarak rute koridor dan jumlah halte yang dilewati menggunakan metode clustering K-Means dan K-Medoids dalam beberapa tahapan, antara lain Tahap Identifikasi Masalah. Tahapan ini adalah mengidentifikasi bagaimana mengelompokkan koridor TransJakarta menggunakan metode klasterisasi K-Means dan K-Medoids.

Tahap kedua adalah Pengumpulan Data. Tahap ini adalah mencari data yang hendak digunakan, seperti jumlah penumpang, jarak rute koridor, dan jumlah halte yang dilewati. Data diambil adalah data dua periode. Periode pertama yaitu sebelum Covid-19 yaitu bulan Agustus 2019 - Maret 2020. Periode kedua yaitu selama Covid-19 yaitu bulan April 2020 - November 2020. Data tersebut berasal dari situs resmi Jakarta Open Data (data.jakarta.go.id) dan transjakarta.co.id.

Data yang diolah menjadi dua bagian yaitu, 8 bulan sebelum Covid-19 dan 8 bulan selama Covid-19.
Ciledug - Blok M). Tujuan dari penelitian ini adalah diharapkan dapat dijadikan bahan pertimbangan dalam alokasi sumber daya, baik itu armada, personel, maupun jadwal pada tiap-tiap koridor.

Tahap ketiga adalah Pengolahan Data dan Implementasi. Setelah dikumpulkan, selanjutnya data diolah menggunakan metode klasterisasi K-Means dan KMedoids. Tahapan diproses melalui perangkat lunak aplikasi spreadsheet, aplikasi Rapid Miner, dan pemograman Python.

Tahap terakhir adalah Evaluasi Hasil Klasterisasi. Pada tahap ini, data dianalisis dalam bentuk cluster model dari pengelompokan koridor TransJakarta berdasarkan jumlah penumpang, jarak rute koridor, dan jumlah halte yang dilewati.

Bagian inti dari penelitian ini adalah proses penambangan data yang akan menghasilkan klaster sesuai dengan pengetahuan atau pola yang tersimpan pada data.

Klasterisasi atau clustering merupakan salah satu metode pengelompokan data berdasarkan kesamaan sifat data. Apabila data tidak memiliki kesamaan sifat, maka akan dikelompokkan dalam kelompok yang lain [12]. Adapun tujuan dari klasterisasi adalah untuk mempartisi objek dalam sebuah cluster (kelompok) yang memiliki kemiripan dibandingkan dengan cluster (kelompok) lain [13].

Algoritma K-Means merupakan salah satu metode clustering melalui atribut numeric [14]. Tahapan dalam implementasi algoritma K-Means, terdiri dari [15] penentuan jumlah cluster, selanjutnya adalah menentukan pusat awal cluster dengan mengambil data secara acak.

Pada tahap selanjutnya dilakukan perhitungan jarak dengan pusat cluster atau centroid menurut persamaan 1 .

$d(x, y)=|x-y|=\sqrt{\sum_{i=1}^{n}\left(x_{i}-y_{i}\right)^{2}}$

Dengan demikian dapat dilakukan penempatan data pada cluster berdasarkan jarak nilai centroid terdekat. 
Adapun penentuan pusat centroid baru dilakukan KDD dimulai. Data hasil seleksi disimpan dalam suatu dengan indikasi, apabila centroid berubah, maka berkas yang terpisah dari basis data operasional. ditetapkan pusat cluster yang baru, menggunakan persamaan 2 .

Pusat Cluster Baru $=\frac{x_{1}+x_{2}+x_{3}+. .+x_{n}}{\text { jumlah } x}$

Dimana $\mathrm{x}_{1}+\mathrm{x}_{2}+\mathrm{x}_{3}+. .+\mathrm{x}_{\mathrm{n}}$ adalah jumlah anggota cluster.

Berbeda dengan Algoritma K-Means, Algoritma KMedoids disebut sebagai varian dari partitioning around medoids. Medoid adalah titik pusat dari suatu cluster. Tahap Transformation, merupakan bentuk kegiatan Tujuan dari medoid dalam setiap cluster adalah untuk coding yang bertujuan agar data agar sesuai untuk mengurangi sensitivitas dari partisi yang dihasilkan pekerjaan-pekerjaan data mining selanjutnya. Proses sebagai nilai-nilai ekstrim yang ada pada dataset [16]. coding merupakan proses yang berkaitan dengan jenis Perbedaan algoritma K-Means dan K-Medoids adalah atau pola informasi yang akan dicari dalam basis data. K-Medoids menentukan nilai $\mathrm{k}$ sebagai objek representative untuk meminimalkan jumlah ketidaksamaan objek data, sedangkan K-Means menentukan jumlah jarak euclidean distance untuk objek data [17]. Tahapan dalam implementasi algoritma Tahap Interpretation/Evaluation, merupakan tahap K-Medoids, dimulai dengan langkah normalisasi hingga untuk mendapatkan hasil penyajian informasi hasil iterasi yang akan berakhir saat anggota klaster tidak penambangan data. Tahap ini dilakukan agar berubah lagi [10].

Pada tahap normalisasi, dilakukan pada data yang akan diolah menggunakan persamaan 3. pengetahuan dapat dimengerti oleh pengguna. Tahap ini Normalized $(x)=\frac{x-\text { MinValue }}{\text { MaxValue-MinValue }}$ Tahap selanjutnya adalah menentukan pusat cluster pemilihan label yang dominan dari setiap hasil sebanyak k (jumlah cluster). Perhitungan jarak dari penerapan algoritma [19]. Pendekatan yang paling setiap data (objek) ke cluster terdekat menggunakan sederhana dan intuitif didasarkan pada aturan majority persamaan (1) sehingga objek dapat ditentukan secara voting yang menetapkan sampel berdasarkan penugasan acak pada masing-masing cluster dengan medoid baru. kelas terbanyak [20]. Aturan majority voting Tahap selanjutnya adalah menghitung jarak setiap objek menetapkan sampel ke kelas yang terkait dengan dengan kandidat medoid baru dan menghitung frekuensi prediksi tertinggi, kecuali jika pembatasan simpangan berdasarkan persamaan 4.

$S=\sum$ nilai distance baru $-\sum$ nilai distance lama

Jika $\mathrm{S}<0$, maka ganti objek dengan data cluster untuk 3. Hasil dan Pembahasan memperoleh sekelompok $\mathrm{k}$ objek yang baru sebagai medoid.

Langkah-langkah untuk melakukan data mining mengikuti aturan KDD (Knowledge Discovery from Proses tersebut berulang sampai tidak ada perubahan Database), dimulai dari tahap seleksi data hingga bentuk cluster dan anggota masing-masing cluster. evaluasi.

Untuk pemecahan masalah penelitian, penelitian ini Pada tahap seleksi, diputuskan menggunakan data 8 mengadopsi pendekatan Knowledge Discovery In bulan sebelum masa pandemi Covid-19 (Agustus 2019 Database (KDD), yaitu serangkaian kegiatan yang sampai dengan Maret 2020) dan 8 bulan awal masa terdiri dari tahap pengumpulan, pemakaian data lampau pandemi Covid-19 (April 2020 sampai dengan yang bertujuan untuk menemukan pola, atau hubungan November 2020). Rentang waktu ini merupakan periode pada set data yang berukuran besar.

Tahap-tahap KDD meliputi kegiatan-kegiatan yang dimulai dari Data Selection hingga Interpretasi atau evaluasi [18]. Tahap Data Selection merupakan pemilihan data dari sekumpulan data operasional perlu dilakukan sebelum tahap penggalian informasi dalam yang unik untuk dianalisis karena pada delapan bulan masa pandemi terjadi fluktuasi penggunaan moda transportasi TransJakarta, berkaitan dengan dimulainya PSBB, pelonggaran dan pengetatan kembali PSBB hingga diberlakukannya PKMM di DKI Jakarta. Data hasil seleksi memiliki 6 atribut, yaitu jenis, kode_trayek, trayek, jumlah_penumpang, panjang_rute, dan jumlah_halte. Berdasarkan tujuan dari penelitian ini,

DOI: https://doi.org/10.29207/resti.v5i3.3041

Creative Commons Attribution 4.0 International License (CC BY 4.0) 
atribut yang dipilih menjadi 4 atribut yaitu trayek, jumlah_penumpang, panjang rute, dan jumlah_halte.

Tahap selanjutnya yaitu Data Preprocessing/Data Cleaning. Sumber data terdiri dari 4 atribut yaitu trayek, jumlah penumpang, panjang rute, dan jumlah halte. Atribut jumlah_penumpang diperoleh dari data jumlah penumpang yang terdapat dalam website data.jakarta.go.id. Sedangkan atribut panjang_rute adalah panjang rute yang dilalui pada tiap koridor, dan atribut jumlah_halte adalah jumlah halte yang dilalui pada tiap koridor. Dari keseluruhan data yang berjumlah 1.403 , beberapa trayek tidak beroperasi selama masa pandemi Covid-19 yang ditandai dengan jumlah penumpang sebanyak 0 atau tidak ada penumpang. Trayek TransJakarta jenis BRT memiliki empat atribut data (trayek, jumlah penumpang, panjang rute, dan jumlah halte), sedangkan trayek lain hanya memiliki 2 atribut (trayek dan jumlah penumpang) dan tidak diperoleh informasi mengenai panjang rute dan jumlah halte. Sesuai dengan tujuan penelitian yaitu mengelompokkan koridor TransJakarta dan ketersediaan data, sehingga data trayek yang dipilih oleh penulis adalah jenis BRT untuk digunakan dalam pemodelan berjumlah 13 yang merupakan koridor utama TransJakarta.

Tahap selanjutnya, proses transformasi data yang dilakukan dengan cara menjumlahkan data jumlah penumpang 8 bulan sebelum masa pandemi Covid-19 menjadi total_penumpang, dan menjumlahkan data jumlah penumpang 8 bulan selama awal masa pandemi Covid-19 menjadi total_penumpang, sehingga diperoleh data yang ditunjukkan pada Tabel 1 dan Tabel 2 berikut.

\begin{tabular}{llll}
\multicolumn{2}{c}{ Tabel 1. Dataset Koridor TransJakarta Sebelum Pandemi } \\
\hline Trayek/ & $\begin{array}{l}\text { Total } \\
\text { Kenumpang } \\
\text { (juta) }\end{array}$ & $\begin{array}{l}\text { Panjang } \\
\text { Rute } \\
(\mathrm{km})\end{array}$ & $\begin{array}{l}\text { Jumlah } \\
\text { Halte }\end{array}$ \\
\hline Koridor 1 & 19,33 & 12,90 & 17 \\
Koridor 2 & 6,96 & 24,20 & 32 \\
Koridor 3 & 8,44 & 19,00 & 16 \\
Koridor 4 & 5,37 & 11,85 & 17 \\
Koridor 5 & 8,50 & 13,50 & 18 \\
Koridor 6 & 8,19 & 13,30 & 20 \\
Koridor 7 & 8,13 & 12,80 & 14 \\
Koridor 8 & 8,56 & 26,00 & 22 \\
Koridor 9 & 11,95 & 29,90 & 27 \\
Koridor 10 & 6,59 & 19,40 & 22 \\
Koridor 11 & 2,68 & 15,00 & 16 \\
Koridor 12 & 2,19 & 23,75 & 25 \\
Koridor 13 & 6,05 & 9,30 & 12 \\
\hline
\end{tabular}

Tabel 2. Dataset Koridor TransJakarta Selama Pandemi

\begin{tabular}{|c|c|c|c|}
\hline $\begin{array}{l}\text { Trayek/ } \\
\text { Koridor }\end{array}$ & $\begin{array}{l}\text { Total } \\
\text { Penumpang } \\
\text { (juta) }\end{array}$ & $\begin{array}{l}\text { Panjang } \\
\text { Rute } \\
(\mathrm{km})\end{array}$ & $\begin{array}{l}\text { Jumlah } \\
\text { Halte }\end{array}$ \\
\hline Koridor 1 & 5,61 & 12,90 & 17 \\
\hline Koridor 2 & 2,41 & 24,20 & 32 \\
\hline Koridor 3 & 3,06 & 19,00 & 16 \\
\hline
\end{tabular}

\begin{tabular}{llll}
\hline Trayek/ & $\begin{array}{l}\text { Total } \\
\text { Penumpang } \\
\text { (juta) }\end{array}$ & $\begin{array}{l}\text { Panjang } \\
\text { Rute } \\
(\mathrm{km})\end{array}$ & $\begin{array}{l}\text { Jumlah } \\
\text { Halte }\end{array}$ \\
\hline Koridor 4 & 1,77 & 11,85 & 17 \\
Koridor 5 & 2,67 & 13,50 & 18 \\
Koridor 6 & 2,35 & 13,30 & 20 \\
Koridor 7 & 2,76 & 12,80 & 14 \\
Koridor 8 & 2,91 & 26,00 & 22 \\
Koridor 9 & 4,55 & 29,90 & 27 \\
Koridor 10 & 2,26 & 19,40 & 22 \\
Koridor 11 & 0,96 & 15,00 & 16 \\
Koridor 12 & 0,94 & 23,75 & 25 \\
Koridor 13 & 1,90 & 9,30 & 12 \\
\hline
\end{tabular}

Tahap utama dari penelitian ini adalah data mining yang dilakukan dengan algoritma K-Means dan K-Medoids pada operasionalisasi menggunakan tiga tools yaitu perangkat lunak aplikasi spreadsheet, aplikasi Rapid Miner, dan pemrograman Python.

3.1. Proses Data Mining menggunakan perangkat lunak aplikasi spreadsheet

Langkah-langkah pada proses klasterisasi dengan algoritma K-Means dijelaskan sebagai berikut:

a) Menentukan nilai $\mathrm{k}$, yaitu cluster yang akan dibentuk. Untuk data sebelum masa pandemi Covid19 nilai $\mathrm{k}$ adalah 3 , sedangkan untuk perhitungan data selama pandemi Covid-19 nilai k adalah 2.

b) Menentukan centroid atau pusat cluster. Centroid dipilih secara acak, sebanyak 3 titik untuk masa sebelum pandemi dan 2 titik untuk masa selama pandemi. Diperoleh titik pusat untuk masing-masing cluster seperti ditunjukkan pada Tabel 3 berikut.

Tabel 3. Titik Pusat Awal pada Setiap Cluster (K-Means)

\begin{tabular}{llll}
\multicolumn{3}{c}{ Tabel 3. Titik Pusat Awal pada Setiap Cluster (K-Means) } \\
\hline & $\begin{array}{l}\text { Total } \\
\text { Penumpang }\end{array}$ & $\begin{array}{l}\text { Panjang } \\
\text { Rute }\end{array}$ & $\begin{array}{l}\text { Jumlah } \\
\text { Halte }\end{array}$ \\
\hline Sebelum Pandemi & & & \\
Cluster 1 & 19,33 & 12,9 & 17 \\
Cluster 2 & 11,95 & 29,9 & 27 \\
Cluster 3 & 2,19 & 9,3 & 12 \\
\hline Selama Pandemi & & & \\
Cluster 1 & 1,77 & 11,85 & 17 \\
Cluster 2 & 2,76 & 12,8 & 14 \\
\hline
\end{tabular}

c) Menghitung jarak setiap objek data terhadap setiap centroid yang terbentuk. Dari perhitungan ini akan diketahui objek data tersebut akan berada pada cluster yang mana. Berikut adalah beberapa contoh perhitungan untuk data sebelum masa pandemi terhadap 3 titik pusat. Perhitungan jarak objek data dengan centroid pertama:

$d 1=\sqrt{(19,33-19,33)^{2}+(12,9-12,9)^{2}+(17-17)^{2}}=0$

Perhitungan jarak objek dengan centroid kedua:

$d 2=\sqrt{(19,33-11,95)^{2}+(12,9-12,9)^{2}+(17-27)^{2}}$ $=21,06065441$

DOI: https://doi.org/10.29207/resti.v5i3.3041

Creative Commons Attribution 4.0 International License (CC BY 4.0) 
Perhitungan jarak objek data dengan centroid ketiga:

$d 3=\sqrt{(19,33-2,19)^{2}+(12,9-9,3)^{2}+(17-12)^{2}}$ $=18,21984364$

Berikutnya adalah contoh perhitungan jarak objek data selama pandemi terhadap 2 titik pusat. Perhitungan jarak objek data terhadap centroid pertama:

$d 1=\sqrt{(5,61-1,77)^{2}+(12,9-11,85)^{2}+(17-17)^{2}}$ $=3,97489065$

Perhitungan jarak objek data terhadap centroid kedua:

$d 2=\sqrt{(5,61-2,76)^{2}+(12,9-12,8)^{2}+(17-14)^{2}}$ $=4,113321049$

d) Memilih jarak terdekat setiap objek data dengan centroid, dan masukkan objek data tersebut ke dalam cluster yang didalamnya terdapat centroid tersebut. Hasil perhitungan iterasi pertama untuk data sebelum pandemi dan selama pandemi dapat dilihat pada Tabel 4 berikut.

Tabel 4. Hasil Perhitungan Iterasi Pertama K-Means

\begin{tabular}{llll}
\hline Masa & $\begin{array}{l}\text { Jumlah } \\
\text { Cluster }\end{array}$ & $\begin{array}{l}\text { Nama } \\
\text { Cluster }\end{array}$ & $\begin{array}{l}\text { Jumlah } \\
\text { Anggota }\end{array}$ \\
\hline Sebelum Pandemi & 3 & Cluster 1 & 1 \\
& & Cluster 2 & 5 \\
& & Cluster 3 & 7 \\
\hline Selama Pandemi & 2 & Cluster 1 & 10 \\
& & Cluster 2 & 3 \\
\hline
\end{tabular}

Setelah semua objek data masuk ke dalam tiap cluster, hitung nilai rata-rata atribut pada tiap cluster untuk dijadikan centroid baru. Berikut adalah beberapa contoh perhitungan centroid baru. Misal pada perhitungan iterasi pertama sebelum pandemi pada cluster 2 terdapat 5 anggota, maka nilai atribut pada tiap objek data dijumlahkan kemudian dibagi jumlah anggota.

$\mathrm{C} 21=(6,96+8,56+11,95+6,59+2,19) / 5=7,247290$

$\mathrm{C} 22=(24,2+26+29,9+19,4+23,75) / 5=24,65$

$\mathrm{C} 23=(32+22+27+22+25) / 5=25,6$

Pada perhitungan iterasi pertama selama pandemi pada cluster 2 terdapat 3 anggota, maka perhitungan centroid baru adalah sebagai berikut:

$\mathrm{C} 21=(3,06+2,76+1,90) / 3=2,572308$

$\mathrm{C} 22=(19+12,9+23,75) / 3=13,7$

$\mathrm{C} 23=(16+14+12) / 3=14$

Keterangan:

$\mathrm{C} 21=$ atribut 1 pada centroid cluster 2.

$\mathrm{C} 22=$ atribut 2 pada centroid cluster 2.

$\mathrm{C} 23=$ atribut 3 pada centroid cluster 2 .

Setelah memperoleh centroid baru, maka proses (b) hingga (d) akan diulang hingga tiap anggota cluster dan centroid tiap cluster tidak mengalami perubahan. Proses berhenti pada iterasi kedua untuk data sebelum pandemi Covid-19 dan proses berhenti pada iterasi keempat untuk data selama pandemi Covid-19.

Langkah langkah pada proses klasterisasi dengan metode $k$-medoids dijelaskan secara rinci dibawah ini:

a) Melakukan normalisasi pada sampel data yang akan diolah, menggunakan rumus (3) di atas. Hasil dari normalisasi data adalah sebagai berikut:

Tabel 5. Normalisasi Data Sebelum Pandemi

\begin{tabular}{llll}
\hline Koridor & $\begin{array}{l}\text { Total } \\
\text { Penumpang }\end{array}$ & $\begin{array}{l}\text { Panjang } \\
\text { Rute }\end{array}$ & $\begin{array}{l}\text { Jumlah } \\
\text { Halte }\end{array}$ \\
\hline Koridor 1 & 1,00 & 0,17 & 0,25 \\
Koridor 2 & 0,28 & 0,72 & 1,00 \\
Koridor 3 & 0,36 & 0,47 & 0,20 \\
Koridor 4 & 0,19 & 0,12 & 0,25 \\
Koridor 5 & 0,37 & 0,20 & 0,30 \\
Koridor 6 & 0,35 & 0,19 & 0,40 \\
Koridor 7 & 0,35 & 0,17 & 0,10 \\
Koridor 8 & 0,37 & 0,81 & 0,50 \\
Koridor 9 & 0,57 & 1,00 & 0,75 \\
Koridor 10 & 0,26 & 0,49 & 0,50 \\
Koridor 11 & 0,03 & 0,28 & 0,20 \\
Koridor 12 & 0,00 & 0,70 & 0,65 \\
Koridor 13 & 0,23 & 0,00 & 0,00 \\
\hline
\end{tabular}

Tabel 6. Normalisasi Data Selama Pandemi

\begin{tabular}{llll}
\hline Koridor & $\begin{array}{l}\text { Total } \\
\text { Penumpang }\end{array}$ & $\begin{array}{l}\text { Panjang } \\
\text { Rute }\end{array}$ & $\begin{array}{l}\text { Jumlah } \\
\text { Halte }\end{array}$ \\
\hline Koridor 1 & 1,00 & 0,17 & 0,25 \\
Koridor 2 & 0,31 & 0,72 & 1,00 \\
Koridor 3 & 0,45 & 0,47 & 0,20 \\
Koridor 4 & 0,18 & 0,12 & 0,25 \\
Koridor 5 & 0,37 & 0,20 & 0,30 \\
Koridor 6 & 0,30 & 0,19 & 0,40 \\
Koridor 7 & 0,39 & 0,17 & 0,10 \\
Koridor 8 & 0,42 & 0,81 & 0,50 \\
Koridor 9 & 0,77 & 1,00 & 0,75 \\
Koridor 10 & 0,28 & 0,49 & 0,50 \\
Koridor 11 & 0,00 & 0,28 & 0,20 \\
Koridor 12 & 0,00 & 0,70 & 0,65 \\
Koridor 13 & 0,20 & 0,00 & 0,00 \\
\hline
\end{tabular}

b) Menentukan nilai k, yaitu jumlah cluster yang akan dibentuk. Untuk data sebelum pandemi Covid-19 nilai $\mathrm{k}$ adalah 3 , sedangkan untuk perhitungan data selama pandemi Covid-19 nilai $\mathrm{k}$ adalah 4.

c) Menentukan medoid atau pusat cluster. Medoid dipilih secara acak, sebanyak 3 titik sebelum masa pandemi, dan 4 titik untuk masa selama pandemi. Diperoleh titik pusat untuk masing-masing cluster seperti ditunjukkan pada Tabel 7.

Tabel 7. Titik Pusat Awal pada Setiap Cluster (K-Medoids)

\begin{tabular}{llll}
\hline & $\begin{array}{l}\text { Total } \\
\text { Penumpang }\end{array}$ & $\begin{array}{l}\text { Panjang } \\
\text { Rute }\end{array}$ & $\begin{array}{l}\text { Jumlah } \\
\text { Halte }\end{array}$ \\
\hline $\begin{array}{l}\text { Sebelum Pandemi } \\
\text { Cluster } 1\end{array}$ & 0,57 & 1,00 & 0,75
\end{tabular}

DOI: https://doi.org/10.29207/resti.v5i3.3041

Creative Commons Attribution 4.0 International License (CC BY 4.0) 
Arief Wibowo, Moh, Makruf, Inge Virdyna, Farah Chikita Venna Jurnal RESTI (Rekayasa Sistem dan Teknologi Informasi) Vol. 5 No. 3 (2021) 565 - 575

\begin{tabular}{llll}
\hline & $\begin{array}{l}\text { Total } \\
\text { Penumpang }\end{array}$ & $\begin{array}{l}\text { Panjang } \\
\text { Rute }\end{array}$ & $\begin{array}{l}\text { Jumlah } \\
\text { Halte }\end{array}$ \\
\hline Cluster 2 & 0,28 & 0,72 & 1,00 \\
Cluster 3 & 0,00 & 0,70 & 0,65 \\
\hline Selama Pandemi & & & \\
Cluster 1 & 1,00 & 0,17 & 0,25 \\
Cluster 2 & 0,77 & 1,00 & 0,75 \\
Cluster 3 & 0,42 & 0,81 & 0,50 \\
Cluster 4 & 0,00 & 0,70 & 0,65 \\
\hline
\end{tabular}

\begin{tabular}{llll}
\hline Masa & $\begin{array}{l}\text { Jumlah } \\
\text { Cluster }\end{array}$ & $\begin{array}{l}\text { Nama } \\
\text { Cluster }\end{array}$ & $\begin{array}{l}\text { Jumlah } \\
\text { Anggota }\end{array}$ \\
\hline & & Cluster 2 & 1 \\
& & Cluster 3 & 9 \\
\hline Selama Pandemi & 4 & Cluster 1 & 1 \\
& & Cluster 2 & 1 \\
& & Cluster 3 & 6 \\
& & Cluster 4 & 5 \\
\hline
\end{tabular}

Setelah semua data masuk ke dalam setiap cluster, baik

Tahap selanjutnya adalah menghitung jarak setiap data perhitungan iterasi pertama maupun iterasi objek data terhadap setiap medoid yang terbentuk. berikutnya, jumlahkan nilai jarak terdekat dari data Dari perhitungan ini akan diketahui objek data tersebut dan tentukan nilai simpangannya. Sebagai tersebut akan berada pada cluster yang mana. contoh, perhitungan simpangan pada data sebelum Berikut adalah beberapa contoh perhitungan untuk pandemi terhadap iterasi pertama dan iterasi kedua: data sebelum pandemi terhadap 3 titik pusat.

Jumlah jarak terdekat iterasi pertama

Perhitungan jarak objek data dengan medoid $=1,06+0+0,62+\ldots+0,98=6,96$

pertama:

$\sqrt{(1-0,57)^{2}+(0,17-1)^{2}+(0,25-0,75)^{2}}$

$d 1=$ Jumlah jarak terdekat iterasi kedua

$=1,056680$

$=0+0,45+0+\ldots+0,53=4,09$

Perhitungan jarak objek data dengan medoid kedua: $d 2=\sqrt{(1-0,28)^{2}+(0,17-0,72)^{2}+(0,25-1)^{2}}$ $=1,1766606$

Perhitungan jarak objek data dengan medoid ketiga: $d 3=\sqrt{(1-0)^{2}+(0,17-0,7)^{2}+(0,25-0,65)^{2}}$ $=1,198921$

Simpangan dari dua hasil penjumlahan jarak terdekat dari setiap iterasi adalah

$\mathrm{S}=4,09-6,96=-2,87$

Berdasarkan perhitungan di atas nilai $\mathrm{S}<0$, maka dilakukan perhitungan berikutnya hingga nilai $\mathrm{S}>0$.

Setelah memperoleh medoid baru, maka proses (b) hingga (d) akan diulang hingga nilai simpangan yang Berikutnya adalah contoh perhitungan jarak objek ditemukan lebih dari nol. Proses berhenti pada pada data selama masa pandemi terhadap 4 titik pusat. iterasi kedua untuk data sebelum pandemi Covid-19 dan Perhitungan jarak objek data dengan medoid data selama pandemi Covid-19. pertama: $d 1=\sqrt{(1-1)^{2}+(0,17-0,17)^{2}+(0,25-0,25)^{2}}=0$ Miner

Perhitungan jarak objek data dengan medoid kedua: $d 2=\sqrt{(1-0,77)^{2}+(0,17-1)^{2}+(0,25-0,75)^{2}}$ $=0,991166$

Perhitungan jarak objek data dengan medoid ketiga: $d 3=\sqrt{(1-0,42)^{2}+(0,17-0,81)^{2}+(0,25-0,5)^{2}}$ $=0,895059$

\subsection{Proses Data Mining Menggunakan Aplikasi Rapid}

Pemodelan K-Means dengan Rapid Miner dibagi menjadi 2 proses yaitu proses klasterisasi koridor TransJakarta sebelum masa pandemi Covid-19 dan selama masa pandemi Covid-19. Proses pemodelan antara data sebelum dan selama pandemi adalah sama, yang membedakan adalah sumber data yang digunakan. Proses pemodelan terlihat pada Gambar 1.

Perhitungan jarak objek data dengan medoid keempat:

$d 4=\sqrt{(1-0)^{2}+(0,17-0,7)^{2}+(0,25-0,65)^{2}}$ $=0,810464$

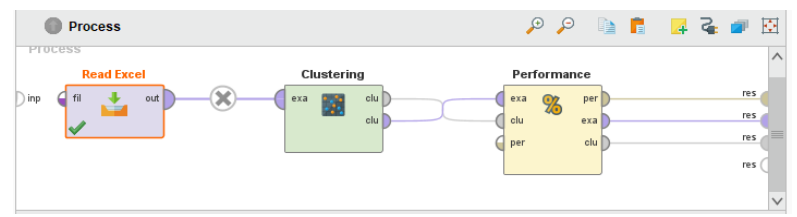

Gambar 1. Pemodelan K-Means dengan Rapid Miner

Memilih jarak terdekat setiap objek data dengan medoid, dan masukkan objek data tersebut ke dalam cluster yang di dalamnya terdapat medoid tersebut. Pada langkah ini dilakukan 4 kali percobaan proses Hasil perhitungan iterasi pertama untuk data sebelum klasterisasi dengan jumlah cluster mulai 2, 3, 4, dan 5 pandemi dan selama pandemi dapat dilihat pada cluster. Hasil klasterisasi dapat dilihat pada Tabel 9. Tabel 8.

Tabel 8. Hasil Perhitungan Iterasi Pertama K-Medoids

\begin{tabular}{llll}
\hline Masa & $\begin{array}{l}\text { Jumlah } \\
\text { Cluster }\end{array}$ & $\begin{array}{l}\text { Nama } \\
\text { Cluster }\end{array}$ & $\begin{array}{l}\text { Jumlah } \\
\text { Anggota }\end{array}$ \\
\hline Sebelum Pandemi & 3 & Cluster 1 & 3
\end{tabular}

Tabel 9. Hasil Pemodelan Rapid Miner (K-Means)

\begin{tabular}{llll}
\hline Masa & $\begin{array}{l}\text { Jumlah } \\
\text { Cluster }\end{array}$ & $\begin{array}{l}\text { Nama } \\
\text { Cluster }\end{array}$ & $\begin{array}{l}\text { Jumlah } \\
\text { Anggota }\end{array}$ \\
\hline Sebelum Pandemi & 2 & Cluster 0 & 8
\end{tabular}

DOI: https://doi.org/10.29207/resti.v5i3.3041

Creative Commons Attribution 4.0 International License (CC BY 4.0) 
Arief Wibowo, Moh, Makruf, Inge Virdyna, Farah Chikita Venna Jurnal RESTI (Rekayasa Sistem dan Teknologi Informasi) Vol. 5 No. 3 (2021) 565 - 575

\begin{tabular}{|c|c|c|c|}
\hline \multirow[t]{14}{*}{ Masa } & $\begin{array}{l}\text { Jumlah } \\
\text { Cluster }\end{array}$ & $\begin{array}{l}\text { Nama } \\
\text { Cluster }\end{array}$ & $\begin{array}{l}\text { Jumlah } \\
\text { Anggota }\end{array}$ \\
\hline & & Cluster 1 & 5 \\
\hline & 3 & Cluster 0 & 5 \\
\hline & & Cluster 1 & 1 \\
\hline & & Cluster 2 & 7 \\
\hline & 4 & Cluster 0 & 7 \\
\hline & & Cluster 1 & 2 \\
\hline & & Cluster 2 & 3 \\
\hline & & Cluster 3 & 1 \\
\hline & 5 & Cluster 0 & 6 \\
\hline & & Cluster 1 & 2 \\
\hline & & Cluster 2 & 2 \\
\hline & & Cluster 3 & 2 \\
\hline & & Cluster 4 & 1 \\
\hline \multirow[t]{14}{*}{ Selama Pandemi } & 2 & Cluster 0 & 8 \\
\hline & & Cluster 1 & 5 \\
\hline & 3 & Cluster 0 & 5 \\
\hline & & Cluster 1 & 4 \\
\hline & & Cluster 2 & 4 \\
\hline & 4 & Cluster 0 & 1 \\
\hline & & Cluster 1 & 7 \\
\hline & & Cluster 2 & 2 \\
\hline & & Cluster 3 & 3 \\
\hline & 5 & Cluster 0 & 5 \\
\hline & & Cluster 1 & 2 \\
\hline & & Cluster 2 & 2 \\
\hline & & Cluster 3 & 2 \\
\hline & & Cluster 4 & 2 \\
\hline
\end{tabular}

Pemodelan K-Medoids dengan Rapid Miner dibagi menjadi 2 proses yaitu proses klasterisasi koridor TransJakarta sebelum masa pandemi Covid-19 dan selama masa pandemi Covid-19. Proses pemodelan antara data sebelum dan selama pandemi adalah sama, yang membedakan adalah sumber data yang digunakan. Pemodelan terlihat pada Gambar 2.

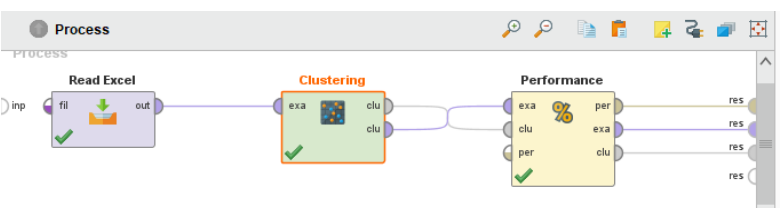

Gambar 2. Pemodelan K-Medoids dengan Rapid Miner

Pada langkah ini dilakukan 4 kali percobaan proses klasterisasi dengan jumlah cluster mulai 2, 3, 4, dan 5 cluster. Hasil klasterisasi dapat dilihat pada Tabel 10 berikut.

Tabel 10. Hasil Pemodelan Rapid Miner (K-Medoids)

\begin{tabular}{llll}
\hline Masa & $\begin{array}{l}\text { Jumlah } \\
\text { Cluster }\end{array}$ & $\begin{array}{l}\text { Nama } \\
\text { Cluster }\end{array}$ & $\begin{array}{l}\text { Jumlah } \\
\text { Anggota }\end{array}$ \\
\hline Sebelum Pandemi & 2 & Cluster 0 & 8 \\
& & Cluster 1 & 5 \\
\cline { 2 - 4 } & 3 & Cluster 0 & 1 \\
& & Cluster 1 & 7 \\
& & Cluster 2 & 5 \\
\cline { 2 - 4 } & 4 & Cluster 0 & 1 \\
& & Cluster 1 & 5
\end{tabular}

\begin{tabular}{|c|c|c|c|}
\hline Masa & $\begin{array}{l}\text { Jumlah } \\
\text { Cluster }\end{array}$ & $\begin{array}{l}\text { Nama } \\
\text { Cluster }\end{array}$ & $\begin{array}{l}\text { Jumlah } \\
\text { Anggota }\end{array}$ \\
\hline & & Cluster 2 & 2 \\
\hline & & Cluster 3 & 5 \\
\hline & 5 & Cluster 0 & 1 \\
\hline & & Cluster 1 & 2 \\
\hline & & Cluster 2 & 3 \\
\hline & & Cluster 3 & 5 \\
\hline & & Cluster 4 & 2 \\
\hline \multirow[t]{14}{*}{ Selama Pandemi } & 2 & Cluster 0 & 7 \\
\hline & & Cluster 1 & 6 \\
\hline & 3 & Cluster 0 & 1 \\
\hline & & Cluster 1 & 5 \\
\hline & & Cluster 2 & 7 \\
\hline & 4 & Cluster 0 & 1 \\
\hline & & Cluster 1 & 1 \\
\hline & & Cluster 2 & 4 \\
\hline & & Cluster 3 & 7 \\
\hline & 5 & Cluster 0 & 4 \\
\hline & & Cluster 1 & 4 \\
\hline & & Cluster 2 & 1 \\
\hline & & Cluster 3 & 3 \\
\hline & & Cluster 4 & 1 \\
\hline
\end{tabular}

3.3. Proses Data Mining Menggunakan Pemrograman Python

Pemodelan K-Means dengan pemrograman Python dibagi menjadi 2 proses yaitu proses klasterisasi koridor TransJakarta sebelum masa pandemi Covid-19 dan selama masa pandemi Covid-19. Pada langkah ini dilakukan 4 kali percobaan proses klasterisasi dengan jumlah cluster mulai 2, 3, 4, dan 5 cluster. Hasil klasterisasi dapat dilihat pada Tabel 11 berikut.

Tabel 11. Hasil Pemodelan Python (K-Means)

\begin{tabular}{|c|c|c|c|}
\hline Masa & $\begin{array}{l}\text { Jumlah } \\
\text { Cluster }\end{array}$ & $\begin{array}{l}\text { Nama } \\
\text { Cluster }\end{array}$ & $\begin{array}{l}\text { Jumlah } \\
\text { Anggota }\end{array}$ \\
\hline \multirow[t]{14}{*}{ Sebelum Pandemi } & \multirow[t]{2}{*}{2} & Cluster 0 & 8 \\
\hline & & Cluster 1 & 5 \\
\hline & \multirow[t]{3}{*}{3} & Cluster 0 & 5 \\
\hline & & Cluster 1 & 7 \\
\hline & & Cluster 2 & 1 \\
\hline & \multirow[t]{4}{*}{4} & Cluster 0 & 7 \\
\hline & & Cluster 1 & 3 \\
\hline & & Cluster 2 & 1 \\
\hline & & Cluster 3 & 2 \\
\hline & \multirow[t]{5}{*}{5} & Cluster 0 & 4 \\
\hline & & Cluster 1 & 3 \\
\hline & & Cluster 2 & 1 \\
\hline & & Cluster 3 & 2 \\
\hline & & Cluster 4 & 3 \\
\hline \multirow[t]{7}{*}{ Selama Pandemi } & \multirow[t]{2}{*}{2} & Cluster 0 & 8 \\
\hline & & Cluster 1 & 5 \\
\hline & \multirow[t]{3}{*}{3} & Cluster 0 & 5 \\
\hline & & Cluster 1 & 7 \\
\hline & & Cluster 2 & 1 \\
\hline & \multirow[t]{2}{*}{4} & Cluster 0 & 1 \\
\hline & & Cluster 1 & 7 \\
\hline
\end{tabular}

DOI: https://doi.org/10.29207/resti.v5i3.3041

Creative Commons Attribution 4.0 International License (CC BY 4.0) 
Arief Wibowo, Moh, Makruf, Inge Virdyna, Farah Chikita Venna Jurnal RESTI (Rekayasa Sistem dan Teknologi Informasi) Vol. 5 No. 3 (2021) 565 - 575

\begin{tabular}{llll}
\hline Masa & Jumlah & Nama & Jumlah \\
Cluster & Cluster & Anggota \\
\hline & Cluster 2 & 1 \\
& Cluster 3 & 4 \\
\cline { 2 - 3 } & & Cluster 0 & 1 \\
& Cluster 1 & 6 \\
& Cluster 2 & 1 \\
& Cluster 3 & 2 \\
& Cluster 4 & 3 \\
\hline
\end{tabular}

\begin{tabular}{llll}
\hline Masa & $\begin{array}{l}\text { Jumlah } \\
\text { Cluster }\end{array}$ & $\begin{array}{l}\text { Nilai DBI } \\
\text { (K-Means) }\end{array}$ & $\begin{array}{l}\text { Nilai DBI } \\
\text { (K-Medoids) }\end{array}$ \\
\hline Sebelum Pandemi & 2 & 0,246 & 0,243 \\
& 3 & $\mathbf{0 , 1 8 4}$ & $\mathbf{0 , 2 0 0}$ \\
& 4 & 0,270 & 0,261 \\
& 5 & 0,272 & 0,247 \\
\hline Selama Pandemi & 2 & $\mathbf{0 , 1 8 8}$ & 0,197 \\
& 3 & 0,323 & 0,202 \\
& 4 & 0,238 & $\mathbf{0 , 1 9 0}$ \\
& 5 & 0,291 & 0,251 \\
\hline
\end{tabular}

Pemodelan K-Medoids dengan pemrograman Python dibagi menjadi 2 proses yaitu proses klasterisasi koridor Dari percobaan yang dilakukan, algoritma K-Means TransJakarta sebelum masa pandemi Covid-19 dan untuk data sebelum masa pandemi, jumlah 3 cluster selama masa pandemi Covid-19. Pada langkah ini menghasilkan kualitas cluster yang lebih baik. Hasil dilakukan 4 kali percobaan proses klasterisasi dengan evaluasi menunjukkan jumlah 3 cluster lebih optimal jumlah cluster mulai 2, 3, 4, dan 5 cluster. Hasil dengan nilai DBI paling kecil, yaitu sebesar 0,184. klasterisasi dapat dilihat pada Tabel 12 berikut.

Tabel 12. Hasil Pemodelan Python (K-Medoids)

\begin{tabular}{|c|c|c|c|}
\hline Masa & $\begin{array}{l}\text { Jumlah } \\
\text { Cluster }\end{array}$ & $\begin{array}{l}\text { Nama } \\
\text { Cluster }\end{array}$ & $\begin{array}{l}\text { Jumlah } \\
\text { Anggota }\end{array}$ \\
\hline \multirow[t]{14}{*}{ Sebelum Pandemi } & \multirow[t]{2}{*}{2} & Cluster 0 & 8 \\
\hline & & Cluster 1 & 5 \\
\hline & \multirow[t]{3}{*}{3} & Cluster 0 & 5 \\
\hline & & Cluster 1 & 4 \\
\hline & & Cluster 2 & 4 \\
\hline & \multirow[t]{4}{*}{4} & Cluster 0 & 4 \\
\hline & & Cluster 1 & 3 \\
\hline & & Cluster 2 & 4 \\
\hline & & Cluster 3 & 2 \\
\hline & \multirow[t]{5}{*}{5} & Cluster 0 & 1 \\
\hline & & Cluster 1 & 3 \\
\hline & & Cluster 2 & 4 \\
\hline & & Cluster 3 & 2 \\
\hline & & Cluster 4 & 3 \\
\hline \multirow[t]{14}{*}{ Selama Pandemi } & \multirow[t]{2}{*}{2} & Cluster 0 & 7 \\
\hline & & Cluster 1 & 6 \\
\hline & \multirow[t]{3}{*}{3} & Cluster 0 & 4 \\
\hline & & Cluster 1 & 3 \\
\hline & & Cluster 2 & 6 \\
\hline & \multirow[t]{4}{*}{4} & Cluster 0 & 3 \\
\hline & & Cluster 1 & 3 \\
\hline & & Cluster 2 & 3 \\
\hline & & Cluster 3 & 4 \\
\hline & \multirow[t]{5}{*}{5} & Cluster 0 & 2 \\
\hline & & Cluster 1 & 3 \\
\hline & & Cluster 2 & 2 \\
\hline & & Cluster 3 & 2 \\
\hline & & Cluster 4 & 4 \\
\hline
\end{tabular}

Hasil Cluster yang terbentuk sebelum dan selama masa pandemi Covid-19 selanjutnya dievaluasi menggunakan Davies Bouldin Index (DBI) seperti ditunjukkan pada Tabel 13.
Sementara itu, selama masa pandemi, jumlah 2 cluster menghasilkan kualitas cluster yang lebih baik. Hasil evaluasi menunjukkan jumlah 2 cluster lebih optimal dengan nilai DBI paling kecil, yaitu sebesar 0,188.

Untuk algoritma K-Medoids, data sebelum masa pandemi, jumlah 3 cluster menghasilkan kualitas cluster yang lebih baik. Hasil evaluasi menunjukkan jumlah 3 cluster lebih optimal dengan nilai DBI paling kecil, yaitu sebesar 0,200. Sementara itu selama masa pandemi, jumlah 4 cluster menghasilkan kualitas cluster yang lebih baik. Hasil evaluasi menunjukkan jumlah 4 cluster lebih optimal dengan nilai DBI paling kecil, yaitu sebesar 0,190 .

Hasil cluster optimal yang terbentuk ditunjukkan pada Tabel 14 berikut, indeks cluster hasil perhitungan manual disesuaikan dengan aplikasi yang dimulai dengan cluster 0 .

Tabel 14. Hasil Cluster Sebelum Pandemi

\begin{tabular}{llllllll}
\hline & $\begin{array}{l}\text { K-Means } \\
(\mathrm{k}=3)\end{array}$ & \multicolumn{5}{c}{$\begin{array}{l}\text { K-Medoids } \\
(\mathrm{k}=3)\end{array}$} & Cluster \\
\hline Koridor & RM* & $\mathrm{P}^{*}$ & $\mathrm{M}^{*}$ & $\mathrm{RM}^{*}$ & $\mathrm{P}^{*}$ & $\mathrm{M}^{*}$ & $\begin{array}{l}\text { Majority } \\
\text { Voting }\end{array}$ \\
\hline 1 & 1 & 2 & 0 & 0 & 1 & 0 & 0 \\
2 & 0 & 0 & 1 & 2 & 2 & 2 & 2 \\
3 & 2 & 1 & 2 & 2 & 0 & 2 & 2 \\
4 & 2 & 1 & 2 & 1 & 0 & 2 & 2 \\
5 & 2 & 1 & 2 & 1 & 1 & 0 & 1 \\
6 & 2 & 1 & 2 & 1 & 1 & 2 & 1 \\
7 & 2 & 1 & 2 & 1 & 0 & 0 & 1 \\
8 & 0 & 0 & 1 & 2 & 2 & 1 & 1 \\
9 & 0 & 0 & 1 & 2 & 2 & 1 & 1 \\
10 & 0 & 0 & 1 & 2 & 1 & 2 & 1 \\
11 & 2 & 1 & 2 & 1 & 0 & 2 & 2 \\
12 & 0 & 0 & 1 & 2 & 2 & 2 & 2 \\
13 & 2 & 1 & 2 & 1 & 0 & 0 & 1 \\
\hline
\end{tabular}

Tabel 13. Nilai DBI

DOI: https://doi.org/10.29207/resti.v5i3.3041

Creative Commons Attribution 4.0 International License (CC BY 4.0) 
Keterangan: RM: Rapid Miner, P: Python, M: Manual

Pada Tabel 14 di atas, dengan menggunakan metode weighted majority voting, cluster yang dihasilkan adalah sebagai berikut:

Cluster 0, sebanyak 1 koridor yaitu Koridor 1. Cluster 0 tersebut merupakan koridor dengan jumlah penumpang 19,33 juta, dengan panjang rute $12,90 \mathrm{~km}$, dan jumlah halte 17.

Cluster 1, sebanyak 7 koridor yang meliputi Koridor 5, Koridor 6, Koridor 7, Koridor 8, Koridor 9, Koridor 10, dan Koridor 13. Cluster 1 tersebut menrupakan koridor dengan rata-rata jumlah penumpang 8,23 juta, dengan rata-rata panjang rute $17,74 \mathrm{~km}$, dan rata-rata jumlah halte 19,29 .

Cluster 2, sebanyak 5 koridor yang meliputi Koridor 2, Koridor 3, Koridor 4, Koridor 11, dan Koridor 12. Cluster 2 tersebut merupakan koridor dengan rata-rata jumlah penumpang 5,12 juta, dengan rata-rata panjang rute $18,76 \mathrm{~km}$, dan rata-rata jumlah halte 21,20.

Tabel 15. Hasil Cluster Selama Pandemi

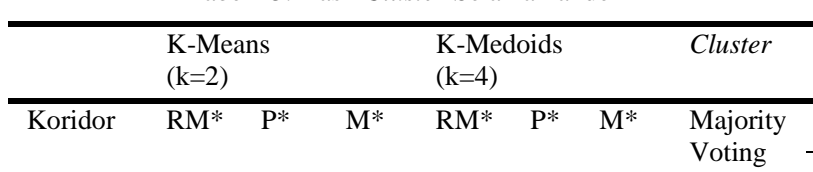

\begin{tabular}{|c|c|c|c|c|c|c|c|}
\hline 1 & 0 & 0 & 1 & 3 & 3 & 3 & 3 \\
\hline 2 & 1 & 1 & 0 & 2 & 2 & 0 & 1 \\
\hline 3 & 0 & 0 & 1 & 3 & 3 & 2 & 0 \\
\hline 4 & 0 & 0 & 1 & 3 & 1 & 3 & 1 \\
\hline 5 & 0 & 0 & 1 & 3 & 0 & 3 & 0 \\
\hline 6 & 0 & 0 & 1 & 3 & 1 & 3 & 1 \\
\hline 7 & 0 & 0 & 1 & 3 & 0 & 3 & 0 \\
\hline 8 & 1 & 1 & 0 & 2 & 2 & 2 & 2 \\
\hline 9 & 1 & 1 & 0 & 0 & 2 & 1 & 1 \\
\hline 10 & 1 & 1 & 0 & 2 & 3 & 2 & 2 \\
\hline 11 & 0 & 0 & 1 & 3 & 1 & 3 & 0 \\
\hline 12 & 1 & 1 & 0 & 2 & 2 & 2 & 2 \\
\hline 13 & 0 & 0 & 1 & 1 & 0 & 3 & 0 \\
\hline
\end{tabular}

Keterangan: RM: Rapid Miner, P: Python, M: Manual

Pada Tabel 15 di atas, dengan menggunakan metode majority voting, cluster yang dihasilkan adalah sebagai berikut:

Cluster 0, sebanyak 5 koridor yang meliputi Koridor 3, Koridor 5, Koridor 7, Koridor 11, dan Koridor 13. Cluster 0 tersebut merupakan koridor dengan rata-rata jumlah penumpang 2,27 juta, dengan rata-rata panjang rute 13,92 km, dan rata-rata jumlah halte 15,20.

Cluster 1, sebanyak 4 koridor yang meliputi Koridor2, Koridor 4, Koridor 6, dan Koridor 9. Cluster 1 tersebut merupakan koridor dengan rata-rata jumlah penumpang 2,77 juta, dengan rata-rata panjang rute $19,81 \mathrm{~km}$, dan rata-rata jumlah halte 24 .
Cluster 2, sebanyak 3 koridor yang meliputi Koridor 8, Koridor 10, dan Koridor 12. Cluster 2 tersebut merupakan koridor dengan rata-rata jumlah penumpang 2.04 juta, dengan rata-rata panjang rute $23,05 \mathrm{~km}$, dan rata-rata jumlah halte 23 .

Cluster 3, sebanyak 1 koridor yang meliputi Koridor 1 . Cluster 3 tersebut merupakan koridor dengan jumlah penumpang 5,61 juta, dengan panjang rute $12,90 \mathrm{~km}$, dan jumlah halte 17 .

Ringkasan hasil klasterisasi yang telah dijelaskan di atas, dapat dilihat pada Tabel 16.

Tabel 16. Hasil Majority Voting

\begin{tabular}{|c|c|c|c|c|}
\hline & Koridor & $\begin{array}{l}\text { Jumlah } \\
\text { Penumpang }\end{array}$ & $\begin{array}{l}\text { Panjang } \\
\text { Rute }\end{array}$ & $\begin{array}{l}\text { Jumlah } \\
\text { Halte }\end{array}$ \\
\hline \multicolumn{5}{|c|}{ Sebelum Pandemi } \\
\hline Cluster 0 & 1 & 19,33 juta & $12,90 \mathrm{~km}$ & 17 \\
\hline Cluster 1 & $\begin{array}{l}5,6,7,8,9 \\
10,13\end{array}$ & 8,23 juta & $17,74 \mathrm{~km}$ & 19,29 \\
\hline Cluster 2 & $2,3,4,11,12$ & 5,12 juta & $18,76 \mathrm{~km}$ & 21,20 \\
\hline \multicolumn{5}{|c|}{ Selama Pandemi } \\
\hline Cluster 0 & $3,5,7,11,13$ & 2,27 juta & $13,92 \mathrm{~km}$ & 15,20 \\
\hline Cluster 1 & $2,4,6,9$ & 2,77 juta & $19,81 \mathrm{~km}$ & 24 \\
\hline Cluster 2 & $8,10,12$ & 2,04 juta & $23,05 \mathrm{~km}$ & 23 \\
\hline Cluster 3 & 1 & 5,61 juta & $12,90 \mathrm{~km}$ & 17 \\
\hline
\end{tabular}

Dari tabel 16 di atas dapat dilihat bahwa, sebelum masa pandemi, Cluster 0 adalah koridor 1 (Blok M-Kota) dengan jumlah penumpang tertinggi dengan rute yang pendek dan jumlah halte sedikit. Cluster 1 adalah koridor-koridor yang sebagian besar berada di wilayah Jakarta Selatan dan sebagian Jakarta Timur, dengan jumlah penumpang sedang, panjang rute sedang, dan jumlah halte sedang. Cluster 2 adalah koridor-koridor yang sebagian besar berada di wilayah Jakarta Barat dan sebagian Jakarta Timur dengan jumlah penumpang paling sedikit, dengan rute terpanjang, dan jumlah halte terbanyak.

Selama masa pandemi, cluster 0 adalah koridor-koridor sebagian besar di wilayah Jakarta Timur, dengan jumlah penumpang sedang, panjang rute sedang, dan jumlah halte paling sedikit. Cluster 1 adalah koridor-koridor yang sebagian besar berada di wilayah Jakarta Selatan, dengan jumlah penumpang sedang, panjang rute sedang, dan jumlah halte terbanyak. Cluster 2 adalah koridorkoridor yang sebagian besar berada di wilayah Jakarta Barat, dengan jumlah penumpang paling kecil, dengan rute terpanjang, dan jumlah halte sedang. Cluster 3 adalah koridor 1 (Blok M-Kota) dengan jumlah penumpang terbanyak, dengan rute dan jumlah halte sedang..

\section{Kesimpulan}

Penerapan metode K-Means dan K-Medoids dalam pengelompokan data koridor TransJakarta dapat

DOI: https://doi.org/10.29207/resti.v5i3.3041

Creative Commons Attribution 4.0 International License (CC BY 4.0) 
menghasilkan beberapa kelompok koridor sebelum masa pandemi Covid-19 dan selama masa pandemi Covid-19. Hasil klasterisasi dapat dijadikan rujukan bagi manajemen TransJakarta untuk mengatur alokasi sumber daya, baik itu armada, personel, maupun jadwal pada tiap-tiap koridor. Berdasarkan hasil pengelompokan yang diperoleh dari penggunaan algoritma K-Means sebelum masa pandemi, jumlah cluster optimal adalah 3 cluster dengan nilai DBI 0,184, dan selama masa pandemi jumlah cluster optimal adalah 2 cluster dengan nilai DBI 0,188. Sementara itu, bila menggunakan algoritma K-Medoids sebelum masa pandemi, jumlah cluster optimal adalah 3 cluster dengan nilai DBI 0,200, dan selama masa pandemi jumlah cluster optimal adalah 4 cluster dengan nilai DBI 0,190.

Pada masa mendatang, penelitian ini dapat dikembangkan dengan menambahkan atribut lain misalnya jumlah transaksi, total nilai transaksi, jumlah transaksi tiap-tiap kartu elektronik, dan atribut lainnya, sehingga cluster yang dihasilkan dapat lebih optimal. Dengan pengembangan atribut diharapkan pengelola TransJakarta memperoleh analisis yang lebih mendalam, berkaitan dengan pelayanan di halte, penyediaan alat baca kartu elektronik, atau unsur pengelolaan lainnya.

\section{Daftar Rujukan}

[1] Giovanni L. A. and Najid N., 2020. Pengaruh ERP Terhadap Perbaikan Pelayanan Waktu Tunggu Dan Waktu Tempuh Transjakarta Pada Ruas Jalan Sudirman-Thamrin. JMTS: Jurnal Mitra Teknik Sipil, vol.3, no. 4, p. 959.

[2] Defiyanti S., Jajuli M., and Rohmawati N., 2017. Optimalisasi KMEDOID dalam Pengklasteran Mahasiswa Pelamar Beasiswa dengan CUBIC CLUSTERING CRITERION. Jurnal Nasional Teknologi dan Sistem Informasi, vol.3, no. 1, pp. 211-218.

[3] Supriyatna A., Carolina I., Janti S., and Haidir A., 2020. Clustering Koridor Transjakarta Berdasarkan Jumlah Penumpang Dengan Algoritma K-Means. Jurnal Sains Komputer \& Informatika (J-SAKTI), vol.4, no. September, pp. 682-693.

[4] Indriyani F. and Irfiani E., 2019. Clustering Data Penjualan pada Toko Perlengkapan Outdoor Menggunakan Metode K-Means. JUITA: Jurnal Informatika, vol.7, no. 2, p. 109.

[5] Sukamto S., Id I. D., and Angraini T. R., 2018. Penentuan Daerah Rawan Titik Api di Provinsi Riau Menggunakan Clustering Algoritma K-Means. JUITA: Jurnal Informatika, vol.6, no. 2, p. 137.

[6] Supriyatna A., Carolina I., Widiati W., and Nuraeni C., 2020. Rice Productivity Analysis by Province Using K-Means Cluster Algorithm. IOP Conference Series: Materials Science and Engineering, vol.771, no. 1.

[7] Gunawan I., Anggraeni G., Rini E. S., and Mustofa Y., 2020. Klasterisasi provinsi di Indonesia berbasis perkembangan kasus Covid-19 menggunakan metode K-Medoids. Seminar Nasional Matematika dan Pendidikan Matematika (5thSENATIK), pp. 301306.
[8] Juninda T., Mustasim, and Andri E., 2019. Penerapan Algoritma K-Medoids untuk Pengelompokan Penyakit di Pekanbaru Riau. Seminar Nasional Teknologi Informasi, Komunikasi dan Industri, vol.11, no. 1, pp. 42-49.

[9] Marlina D., Lina N., Fernando A., and Ramadhan A., 2018. Implementasi Algoritma K-Medoids dan K-Means untuk Pengelompokkan Wilayah Sebaran Cacat pada Anak. Jurnal CoreIT: Jurnal Hasil Penelitian Ilmu Komputer dan Teknologi Informasi, vol.4, no. 2, p. 64.

[10]Pramesti D. F., Lahan, Tanzil Furqon M., and Dewi C., 2017. Implementasi Metode K-Medoids Clustering Untuk Pengelompokan Data Potensi Kebakaran Hutan/Lahan Berdasarkan Persebaran Titik Panas (Hotspot). Jurnal Pengembangan Teknologi Informasi dan Ilmu Komputer, vol.1, no. 9 , pp. $723-732$

11]Retno Utari D. and Wibowo A., 2020. Pemodelan Prediksi Status Keberlanjutan Polis Asuransi Kendaraan dengan Teknik Pemilihan Mayoritas Menggunakan Algoritma-Algoritma Klasifikasi Data Mining. Prosiding Seminar Nasional Teknoka, vol.5, no. 2502, pp. 19-24

[12]Praja B. S., Kusuma P. D., and Setianingsih C., 2019. Penerapan Metode K-Means Clustering Dalam Pengelompokan Data Penumpang Dan Kapal Angkutan Laut Di Indonesia. eProceeding of Engineering, vol.06, no. 1, p. 1442.

[13]Nugroho D., Nhita F., and Trantoro D., 2016. Prediksi Penyakit Menggunakan Genetic Algorithm ( GA ) dan Naive Bayes Untuk Data Berdimensi Tinggi Prediction of Disease Using Genetic Algorithm ( GA ) and Naive Bayes For Data High Dimension. $e$ Proceeding of Engineering, vol.3, no. 2, pp. 3889-3899.

[14]Ningrat D. R., Maruddani D. A. I., and Wuryandari T., 2016. Analisis Cluster Dengan Algoritma K-Means Dan Fuzzy C-Means Clustering Untuk Pengelompokan Data Obligasi Korporasi. Jurnal Gaussian, vol.5, no. 4, pp. 641-650.

[15]Bastian A., Sujadi H., and Febrianto G., 2018. Penerapan Algoritma K-Means Clustering Analysis Pada Penyakit Menular Manusia (Studi Kasus Kabupaten Majalengka). Jurnal Sistem Informasi, vol.14, no. 1, pp. 26-32.

[16] Sindi S., Ningse W. R. O., Sihombing I. A., Ilmi R.H.Zer F., and Hartama D., 2020. Analisis Algoritma K-Medoids Clustering Dalam Pengelompokan Penyebaran Covid-19 Di Indonesia. JTI (Jurnal Teknologi Informasi), vol.4, no. 1, pp. 166-173.

[17]Listiyanti D., Syahbana Y. A., and Henim S. R., 2016. Perancangan dan Implementasi Aplikasi Android Penentu Salient Area pada Video dengan Algoritma K-Medoids. Annual Research Seminar: Computer Science and Information and Communications Technology, vol.2, no. 1, pp. 96-101.

[18] Mahartika I. R. and Wibowo A., 2019. Data Mining Klasterisasi dengan Algoritme K-Means untuk Pengelompokkan Provinsi Berdasarkan Konsumsi Bahan Bakar Minyak Nasional. Prosiding Seminar Nasional SISFOTEK (Sistem Informasi dan Teknologi), vol.3, no. 1, pp. 87-91.

[19] Satmoko D. B., Sukarno P., and Jadied E. M., 2018. Peningkatan Akurasi Pendeteksian Serangan DDoS Menggunakan Multiclassifier Ensemble Learning dan Chi-Square Pendahuluan Studi Terkait, vol.5, no. 3, pp. 7977-7985.

[20]Patil D. R. and Patil J. B., 2018. Malicious URLs detection using decision tree classifiers and majority voting technique. Cybernetics and Information Technologies, vol.18, no. 1, pp. 1129.

21]Alotaibi B. and Elleithy K., 2016. A majority voting technique for Wireless Intrusion Detection Systems. 2016 IEEE Long Island Systems, Applications and Technology Conference, LISAT 2016, no. October 2017. 